\title{
FORM AND SUBSTANCE IN FIELD WAREHOUSING*
}

\author{
Harold F. Birnbaum $\dagger$
}

The inventory of a merchant or manufacturer is in many cases the reason why he needs credit and at the same time the soundest basis for extending credit to him.

Inventory is capital, in the most orthodox sense of that term. Inventory is goods-surplus which has not been consumed.

Whether we look at the largest manufacturer or the smallest merchant, the well-established concern or the person who is just gathering funds with which to start, the same analysis holds true: he needs inventory before he can commence operations or open his doors. Someone's capital, someone's accumulated savings, must be placed at his disposal before he can start.

Capital is also required for machinery and fixtures and in order to carry receivables until they are converted into cash. However, the requirements of capital for inventory are always fundamental.

An appreciation of this analysis is essential to an understanding of the various types of inventory financing and to an appraisal of the legal and socio-economic problems which must be encountered and solved as a prerequisite to the sound functioning of this portion of the banking phases of our business system.

Trust receipt, factor's lien, chattel mortgage, pledge, consignment, commercial warehousing and field warehousing are all different methods of supplying capital for inventory on a secured basis, just as sales on credit to a business, bank borrowings, and long-term credits may, on an unsecured basis, supplement the capital directly invested.

A conclusion as to whether any or all of these security transactions should be encouraged and facilitated requires consideration of their functioning, recognition of the fact that they are only methods and not results, and adoption of a business philosophy which will reduce the friction or waste with which desirable methods can be employed.

\section{The Mechanics of Field Warehousing}

Field warehousing accomplishes the same end result as a direct pledge of the goods. This is done through a bailment of the goods in the true sense of the word,

- The cases in this field are assembled in Friedman, Field Warehousing, 42 Cor. L. REv. 991 (1942); Kane, The Theory of Field Warehousing, 12 WASH. L. REv. 20 (r937); Note, x9 CALIF. L. REv. 333 (I93I); r33 A. L. R. 209, esp. 234-250. Operating problems are discussed in WEstey J. SchNEIDER, Field Warehousing (194I), Raymond J. Saulnier and Neil H. Jacoby, Financing Inventory on Field Warehouse Receipts 3 (I944). See also P-H Bankr. Serv. \$22001.

† A.B. 1920, University of Colorado: LL.B. 1923, Harvard Law School. Member of Massachusetts, New York, and California bars. Author, The Auto Finance Consent Decree-A New Technique in Enforcing the Sherman Act, 24 WASH. U. L. Q. 525 (1939). 
followed by a pledge of documents of title which have roots in the same law merchant from which we obtained bills of exchange, bills of lading, and other necessities of commerce.

I. The first step is to effect a change of possession of the inventory, by delivery to a third party as bailee.

2. The next step is for the bailee to give a receipt for the inventory so delivered.

3. The third step is for the bailor to pledge the receipt to the lender as security for the loan.

The mechanics of field warehousing are often attacked as being more form than substance. This results in basic problems, both business and legal.

\section{II}

\section{Elements of "Form" in the Delivery of Possession}

The first element of form is the location of the warehouse on the borrower's premises- "in the field"-hence the derivation of the operation's name. A corner of the factory premises is fenced off, or a room in a factory building is locked. This segregated area is leased to a warehouse company for a nominal rent and constitutes the warehouse. ${ }^{1}$

The second element of form is the structure of the warehouse company. Sometimes it is one of several which engage in field warehousing throughout the country as their sole business. Sometimes it is a corporation especially organized, or an individual especially selected, for the single operation between the particular borrower and lender.

The third element of form is the personnel of the warehouse company. Conventionally, the personnel is limited to one individual who is selected from among the employees of the borrower, ${ }^{2}$ covered by a fidelity bond, and put on the payroll of the warehouse company. His employment is emporary, for the duration of the warehouse operation, and he expects to go back on the borrower's payroll after the warehousing terminates. In addition to his duties as manager of the warehouse company, he continues to perform his regular duties for the borrower while the warehousing is in effect.

The fourth element of form is the compensation of the warehouse company. The warehouse charges are sufficient only to cover the nominal rent and the salary of the single employee, plus the premium on his fidelity bond. When the operation is administered by a company engaged in the business on a nationwide scale, the warehouse charges also include a relatively moderate supervisory fee. However, the

\footnotetext{
${ }^{2}$ Such a lease has been held not to violate a covenant against subleasing. Mercury Electronic Lab. oratories v. Krug, 330 Ill. App. 336, 7 I N. E. $2 d$ 104 (1947).

${ }^{2}$ Under the United States Warehouse Act, 39 STAT. 486 (Igr6), 7 U. S. C. \$241 (I940), the Administrator will not license a warehouse supervised by former personnel (see H. S. Yohe, Fibr. Warehouse Receipts-Collateral or No Collateral (Bureau of Agricultural Economics, U. S. Dep't of Agric. 1937)); and bankers' acceptances secured by receipts issued by a warehouse with such supervision are not eligible for rediscount (see 23 FED. Res. BuLc. 518 (I937)). The courts generally give validity to such warehouse receipts (see cases cited below; esp. notes I9 and 22).
} 
elements of capital investment, risk, and profit incident to a normal commercial warehousing enterprise are never present.

The fifth element of form is the facilities of the warehouse. Even though the bailee has actual possession, neither the fence on the lot nor the lock on the door is regarded by any of the parties as being physically strong enough to afford adequate protection against a determined attempt at forcible entry by the borrower. As far as the borrower is concerned, they remind one of Mary Garden's strapless evening gown: "It is held up by your self-restraint, Mr. Depew." There are no burglar-proof doors to the warehouse and no separate fire alarms; refrigeration or other special protective facilities are supplied by the borrower.

The sixth element of form is the exclusiveness of the warehouse. Warehousing is ordinarily a public calling, like that of a common carrier or a public weighmaster. The ordinary warehouseman will store the goods of all who offer, and his "negotiable warehouse receipts" are given currency as documents of title on that basis. The field warehouseman, on the other hand, is physically incapable and practically unwilling to act for more than one party at the same field warehouse.

When there is rigorous adherence to the formal requirements of possession by the bailee-warehousemen, these elements of form have real substance and are given legal validity. As a result, the practical business interests are well served by the ingenious adaptation of general mechanics to the requirements of a specific commercial enterprise.

The most important requirement is to avoid unnecessary handling and transportation. It would be an economic waste to move a manufacturer's finished inventory, which is awaiting sale or delivery, from the factory to a public warehouse for storage until shipment, so long as space is available on the borrower's premises. Whether the product is finished lumber, canned food, wine in casks, or coal, no good business purpose is served by merely moving it from one resting place to another.

Where the commodity is raw material, the convenience of the borrower is also served by the location of the warehouse on his premises. The commodity may be eggs waiting to be powdered, steel to be fabricated, or tubes, condensers, and other parts to be assembled into a radio. Unless the goods are at hand, and can be used as a whole or selected by grades and quantities without delay, the operation is not practical.

The same considerations apply to personnel. No field warehouse requires the full-time services of all the men and machines which it uses. The manager and the clerical help, the trucks, hoists, and labeling apparatus-these and all else would be idle most of the time if devoted solely to the service of the warehouse.

The statement made by $\mathrm{Mr}$. Justice Brandeis in connection with the development of loan receipts in the field of marine insurance is equally applicable to field warehousing: 
It is creditable to the ingenuity of business men that an arrangement should have been devised which is consonant both with the needs of commerce and the demands of justice. ${ }^{3}$

\section{III}

\section{Problems of Business Substance in Field Waremousing}

Most of the business problems are not such as to require extended discussion in the present article. In the first place, loans on goods in a field warehouse are commodity loans. They are sound to the extent that the commodity is salable, and the lender must gauge the extent of the loan in the light of fluctuating commodity prices.

Second, the lender must establish his own safeguards as to the intrinsic value of the warehoused goods. Generally, he relies on the borrower's count, as certified by the borrower's employee who is now the bonded manager of the warehouse. Common prudence requires at least periodic physical test-checks as to quantity and quality, to be made by the lender's own employees or by actually independent agencies. Unless this is done the lender may wake up too late and find a serious shortage, too large to be covered by the employee's fidelity bond; or else the lender may discover that the canned applesauce has become unsalable because of discoloration due to unanticipated chemical reaction inside the container; or the lender may find that, although the inventory was properly balanced at the outset, the woolen goods left in the warehouse are flannels when the market currently demands gabardines.

Third, the transition from raw materials to finished goods calls for flexibility and accuracy. For example, the field warehouse may be operated in connection with a powdered-egg plant. When the raw eggs are delivered into the warehouse they must be covered by warehouse receipts and valued as collateral. The following day they must be released to the processing department, whereupon they cease to be covered by the warehouse receipt. After the processing is completed the cases of powdered eggs go into the warehouse, are covered by new warehouse receipts, and are revalued as collateral. This procedure requires accurate instructions and record-keeping so far as the warehouse manager is concerned, and also raises a separate problem concerning possible "preferences" in case of bankruptcy."

This problem may be illustrated as follows: Suppose that on March $I$ the loan to an egg-powdering plant, as a typical processor for field-warehousing purposes, is $\$ 100,000$, and is secured by warehouse receipts covering raw eggs at a market value of $\$ 60,000$ and powdered eggs at a market value of $\$ 60,000$, under a loan agreement

${ }^{3}$ Luckenbach v. McCahan Sugar Refining Co., 248 U. S. 139, 149 (1918).

"In re Baumgartner, 55 F. 2d I04I, 1047 (C. C. A. 7th 193r); Wolfe v. Bank of Anderson, 238 Fed. 343 (C. C. A. $4^{\text {th }}$ I9I6). The problem is similar to that involving "day loans" by banks to stockbrokers. National City Bank v. Hotchkiss, 231 U. S. 50 (1913); Mechanics' \& Metals National Bank v. Ernst, 23 I U. S. 60 (I913); $c f$. Sexton v. Kessler \& Co., 225 U. S. 90 (1912). The business necessity: of day loans was recognized in New York by statutory protection through an amendment to Section 230 of the New York Lien Law. N. Y. LIEN LAw \$230, c. 33. Irving Trust Co. v. Bank of Amcrica National Ass'n, 68 F. 2d 887 (C. C. A. 2d I934). 
requiring the maintenance of collateral in the ratio of six to five. ${ }^{5}$ Assume that the borrower is on that date known to be insolvent; but the lender does not enforce his remedies regarding the loan, expecting that the borrower may be able to work himself out of his financial difficulties. Day after day raw eggs are released from the warehouse for processing. While they are being processed they are no longer in the possession of the warehouse nor covered by the warehouse receipt. After processing is finished, powdered eggs are delivered into the warehouse and new receipts are issued. After some weeks, the borrower's expectations are disappointed and bankruptcy results. Are all of the pledges of warehouse receipts, covering powdered eggs delivered into the warehouse after the lender knew of the insolvency, to be treated as voidable preferences in bankruptcy? Such a result would be a windfall to general creditors and would discourage continued help from secured creditors when it is most needed. However, unless this result is to follow, careful mechanics must be arranged in advance and adhered to so that substitution of collateral can be effected simultaneously with or in advance of the release of collateral$i$.e., the substitution must occur at or before the time when the raw eggs are released, and not at the time when the powdered eggs are delivered to the warehouse. ${ }^{6}$

\section{IV}

\section{Who May Be the Warehouseman?}

The Uniform Warehouse Receipts Act has now been adopted throughout the United States, inciuding the District of Columbia, Alaska, and Puerto Rico, and in the Philippines. Section I of the Act provides that "warehouse receipts may be issued by any warehouseman." Section $5^{8}$ of the Act defines a warehouseman as "a person lawfully engaged in the business of storing goods for profit."

The issue whether the borrower may set up a company or an individual to act solely as warehouseman for the borrower's goods, for the purpose of a field-ware-

\footnotetext{
'Conceivably, the loan agreement may provide for repayments to the lender whenever any raw material is released from the warehouse for processing or any finished goods are released for shipment, and for fresh loans to the borrower whenever any raw material or finished goods are delivered to the warehouse. In practice, the parties frequently seek to avoid what they regard as red tape and prefer to reduce the number of payments and repayments by having the loan remain at a stationary amount so long as it is adequately secured.

oMere exchange of collateral is not a preference. IV-A REMINGTON on BANRRUPTCY \$1673 (5th ed. 1943). In jurisdictions where trust receipts are valid, either at common law or under the Uniform Trust Receipts Act, and to the extent that they are upheld under $\$ 602$ of the Bankruptcy Act, the inventory in process can be covered under trust receipts. The warehouse receipt on raw eggs is exchanged for a trust receipt, which is later exchanged for a warehouse receipt on powdered eggs. In other jurisdictions it was the writer's practice to instruct the warehouseman that he was authorized to release colIateral on a particular day only if the total collateral on deposit at the close of the previous day exceeded the agreed minimum by at least the amount to be released. For example, in the illustration under consideration, if the total value of raw and powdered eggs on deposit at the close of one day was $\$ 128,000$, the warehouseman was authorized to release up to $\$ 8,000$ of raw eggs for processing on the following day. It is clear that the lender must insist on literal obedience to such instructions and cannot acquiesce in a practice of releasing whatever amount the borrower may desire in excess of the permitted quantity. In re C. A. Taylor Log \& Lumber Co., 4 I F. 2 d 249 (W. D. Wash. 1925). The practice described was never tested in court in any instance where -it was employed, but it is believed to be sound. Cf. In re Pusey, Maynes, Breish Co., 122 F. 2d 606 (C. C. A. 3d I94I).
} 
housing operation, has been passed upon in a number of cases arising under the Act. In Citizen's Bank v. Willing, ${ }^{7}$ the borrower, Red Cedar Company, organized a warehouse company under the name of Fidalgo Warehouse Company. Salmon-box shooks, upon manufacture by the borrower, were placed in a separate room or shed on the borrower's premises and a negotiable warehouse receipt was issued therefor by the warehouse company and deposited by the borrower with a bank as collateral. After quoting the definition of "warehouseman" from the Act, the court held:

In this case the Fidalgo Warehouse Company had no separate building of its own; it did not store goods for the public generally or at all; it only stored the product of the Red Cedar Company in a room or shed upon the premises of that company. It was simply a device by which the bank was furnished negotiable warehouse receipt[s] as collateral security for the loans which it had made to the Red Cedar Company. The evidence fails to show that the warehouse company was storing goods for profit, and therefore it would not come within the statutory definition. ${ }^{8}$

In Continental Can Company v. Jessamine Canning Company Jessamine Canning Company by resolution of its directors agreed to place its canned goods in the custody of F. D. Smith, Jr., its bookkeeper, as warehouseman. It then ran a wire partition through its building, cutting off the space in which the manufactured product was stored from the other part of the building where its machinery was installed and operated. Pursuant to the agreement, the warehouseman issued negotiable warehouse receipts, which were pledged to secure loans. The plaintiff attached the warehoused goods. The Kentucky court, also in reliance on the statutory definition, as well as on the basis of cases decided before the adoption of the Uniform Warehouse Receipts Act, held that the term "warehouseman" referred only to persons engaged in the business of storing goods, not only for themselves and in their own plant, but for others as well.

Thus it is clear that the warehouseman cannot be a mere dummy, but must be a person engaged in the business of storing goods for profit. The borrower's company clearly does not fall within this category. An independent warehouse company clearly does.

Probably a lender who is engaged in large-scale field-warehousing operations and who possesses corporate power to own a warehouse subsidiary could set up a warehouse company to engage in the business of operating such warehouses for profit at the various locations where the goods of the various borrowers are to be stored. Such a warehouse company would seem to qualify under the statutory definition, if operated for profit and on a sufficiently wide scale. Further than this it would be unsafe to go.

In Lippincott Distributing Co. v. Peoples Commercial and Savings Bank, ${ }^{10}$ the officers of the borrower, Union Grocers, Inc., organized the Union Commercial

Iog Wash. 464,186 Pac. ro72 (rg20).

Id. at ro74.

- $286 \mathrm{Ky} .365$, r5o S. W. $2 d 922$ (194r).

${ }^{10} 137$ Ohio St. 399, 30 N. E. $2 d 69 \mathrm{r}$ (1940). 
Warehouse Company. The two companies had interlocking officers and the warehouse company occupied the same building as the borrower. The merchandise consigned to Union Grocers was placed in the warehouse and warehouse receipts were pledged with a bank. In litigation between the consignor of the goods and the bank it was argued that the Union Commercial Warehouse Company was not a bona fide warehouseman under the Uniform Warehouse Receipts Act. The court held in favor of the bank on the ground that, so far as the bank knew or had reason to believe, the Union Commercial Warehouse Company was a bona fide warehouse company. Regardless of the correctness of this holding on the facts, upon the basis of which the doctrine of estoppel was invoked against the consignor, the case is no authority to support the practice of setting up individual warehouse companies for single borrowing operations.

\section{$\mathrm{V}$}

\section{Possession OF THE WaREHOUSE}

The leading case on field warehousing is Union Trust Company v. Wilson. ${ }^{11}$ The facts are stated in the opinion:

The bankrupt, Flanders, was a wholesale leather dealer. He walled off a part of the basement of his place of business, and let it at a nominal rent to the Security Warehousing Company. There were doors to this part, with padlocks bearing the name of the company, which were kept locked and to which the company had the only keys. The company had a key to Flanders' front door and access to the part let to it, at all hours of day or night. No one else could get such access without breaking in. There were two signs on the outside, stating in large letters that the premises were occupied by the company as a public warehouseman. The company received leather from Flanders into this place, issuing a certificate that it had received the same on storage subject to the order of $\mathrm{H}$. L. Flanders \& $C_{0}$., and identifying the leather; "said commodity to be retained on storage and delivered only upon surrender of this receipt properly endorsed and payment of all charges thereon." To every parcel of the leather was attached a card legibly stating that it was in the possession of the Warehouse Company. The company stipulated in the receipt against liability for damage by fire, water, etc., and by a general contract with Flanders the latter assumed all risk of loss except from dishonesty of the company's servants. Flanders paid the company twenty dollars a month for the first \$ro,0oo worth of property or less, and a dollar a month for each additional $\$$ r,ooo. He also paid the expenses of the company in connection with storing the goods. The certificates of the company issued as above were all endorsed by Flanders to the Union Trust Company as security for loans made by it to him in the regular course of business. If Flanders desired to remove any part of the leather he paid the necessary sum to the Trust Company, was entrusted with the receipts, got the Warehouse Company to send a man to unlock the place of enclosure and allow the removal, endorsing on the receipt the amount delivered if less than all, and then, as the case might be, returned the receipt to the Trust Company or surrendered it into the Warehousing Company's hands. ${ }^{12}$

The opinion of the Court, written by Mr. Justice Holmes, sustains the validity of the warehousing transaction. The Court first held that the principle of law involved

${ }^{12}$ I98 U. S. 530 (1905).

${ }^{12}$ Id. at 534-535. 
was that of bailment. It then held that the warehousing company had possession of the goods because it had them under lock and key in a place to which it had a legal title and right of access by lease. The Court went on to speak as follows:

We deal with the case before us only. No doubt there are other cases in which the exclusive power of the so-called bailee gradually tapers away until we reach those in which the courts have held as matter of law that there was no adequate bailment. Bank v. Jagode, I86 Pa. St. 556; Drury v. Moors, I7I Massachusetts, 252. So, different views have been entertained where the owner has undertaken to constitute himself a bailee by issuing a receipt. We may concede, for purposes of argument, that all the forms gone through in this case might be emptied of significance by a different understanding between the parties, which the form was intended to disguise. But no such understanding is stated here, and it cannot be assumed. There is no reason even to infer it as a conclusion of fact, if such inferences were open to us to draw. It is true that the evident motive of Flanders was to get his goods represented by a document for convenience of pledging rather than to get them stored, and the method and amount of compensation show it. But that was a lawful motive and did not invalidate his acts if otherwise sufficient. He could get the goods by producing the receipt and paying charges, of course, but there is no hint that the company did not insist upon its control. It is suggested that the goods gave credit to the owner. But, in answer to this, it is enough to say that the goods were not visible to any one entering the shop. They could be surmised only by going to the basement, where signs gave notice of the company's possession, and probably could be seen only if the company unlocked the doors. There is nothing stated which warrants us in doubting that all the transactions were in good faith. ${ }^{13}$

The principles of the Wilson case run through all the other decisions in which the courts are called on to determine whether the bailee-warehouseman has open, notorious, and exclusive possession-or, in the language of Mr. Justice Holmes, "conscious control, the intent to exclude and the exclusion of others, with access to the place of custody as of right."14

For example, in In re Rodgers, ${ }^{15}$ where the court refused to uphold the validity of the operation, it said:

We are thus brought to the consideration of the real character and purpose of the transaction between the bankrupt and the storage company. We are to ascertain the real intention of the contracting parties from the whole agreement read in the light of the surrounding circumstances. The bankrupt was largely engaged in purchasing seed upon credit, storing the property purchased in his warehouse. He occupied the premises as a place of business, maintaining an office there, with clerks to assist in the management of the business, and with porters to handle the seed. The premises were subject to a rental of $\$ 250$, a month. He arranged with the storage company, which had no warehouse of its own, that it would issue warehouse warrants or receipts to the bankrupt for property upon the bankrupt's premises for a certain small charge per month upon the value of the property covered by the receipts. He executed a lease of the premises to the storage company, to continue so long as the bankrupt should desire, and so long as property remained thereon for which warrants or receipts had been issued; and this without any

1s Id. at 537-538.

${ }^{14} \mathrm{Id}$. at 537 .

${ }^{26} 125$ Fed. 169 (C. C. A. 7th 1903). 
payment of rent by the storage company, the rental in fact being paid by the bankrupt. The storage company neither required, nor was it given, any key to the premises. The bankrupt remained in possession of the premises as before the agreement, continuing to transact his business there as he had formerly done. There were certain signs placed upon the different floors of the building, indicating that the storage company controlled the premises. These were small and obscure signs, not likely to attract attention, and most of them hidden behind the piles of bags of seed. No sign was displayed upon the exterior of the building indicating any proprietorship of the storage company, or giving notice to the world that any other than the bankrupt had possession and control. There was no open, notorious manifestation of a change of possession, none was intended, and there was none in fact. Upon each pile of bags of seed for which the warehouse receipts or warrants were issued there was placed a small tag, which might be discovered upon careful search. The bankrupt substantially treated this property as his own, at times going through the forms prescribed by the storage company, and, whenever he found it necessary, ignoring them. We do not find that the storage company had knowledge of this action of the bankrupt, but it certainly knew that it was possible under the circumstances for the bankrupt to do with the property as he would, since it was left within his control.

It is difficult for us to look upon this transaction as a warehousing of property. The storage company assumed no liability to the bankrupt, and assumed only such responsibility as the law imposes upon it with respect to those advancing money upon the faith of its warehouse warrants or receipts. The name of the company is in itself, under the circumstances, a false pretense. It did not store property. It had no premises upon which to store property. The bankrupt stored the property. The bankrupt paid the rental of the premises. It is true that an agent of the storage company occasionally visited the premises and inspected the property in a sort of a way, but exercised no supervision or control that would prevent the bankrupt from doing with it as his will might dictate or his financial necessities might require. We cannot but regard this arrangement as a subterfuge, a mere device to enable the bankrupt to hypothecate the warehouse warrants or receipts, and so to raise money upon secret liens upon property in his possession and under his control. The written agreement indicates this. It is somewhat startling to learn that a warehouse company should store goods of this character for another upon the premises of that other, taking compensation as for storage, not related to the cost of storage, or to the expense of receiving and delivering the property, not according to the space occupied by the property, but according to the value of the property. The fact here is patent that the storage company assumed to the bankrupt no liability, and that the sole purpose was to issue warehouse warrants or receipts, making such inspection only 2s, in its judgment, would protect it from liability to third persons by reason of the issue of its warrants. To uphold such a scheme would permit every merchant in the state, notwithstanding the declared policy of the state to the contrary, to have possession of large stocks, thereby inducing credit, and to cover them with secret liens, thereby deceiving creditors. It would, in effect, permit such merchant to pledge his entire stock without change of possession, without record of it, and without notice to the world. Such a scheme is disapproved by the law of the state of Illinois, which in this instance we are bound to uphold, however specious may be the device or however attractive may be the form by which it is cloaked. Such a scheme within the state of Illinois is constructively fraudulent as to creditors, and voidable by creditors. ${ }^{10}$

10 Id. 2t 177-179. 
This case should be contrasted with two recent cases in which properly designed warehousing operations were sustained.

In Heffron v. Bank of America National Trust and Savings Association, ${ }^{17}$ the facts were stated by the court as follows:

The bankrupt, a wholesale and retail merchant in the city of Los Angeles, was engaged in the sale of unfabricated steel of various kinds and dimensions. He kept a portion of his inventory and maintained his office at $6_{33}$ South Anderson Street, and deliveries were made from this address. A small part of the front was occupied by the bankrupt as his office and the balance of the building was used for the storage of steel, the warehouse portion being separated from the office by walls or partitions through which there was a door.

Desiring to procure credit on the security of his stock, the bankrupt on July 20, 1937, entered into a leasing and field warehouse storage agreement with the Lawrence Warehouse Company, operating an extensive system of field warehouses, to establish a warehouse on his premises. Under this agreement the bankrupt leased to the Warehouse Company the building mentioned, with the exception of the office, for the yearly rental of one dollar. The Warehouse Company undertook to act as custodian of all goods then on the premises and of any other goods placed there, in consideration of the sum of fifty cents per ton per month for goods stored which were covered by warehouse receipts, with a minimum charge of $\$ 500$ for the first year. It conspicuously marked the building, inside and out, with "No Trespassing" placards and with large signs bearing the name of the Warehouse Company and a statement to the effect that "all commodities in or upon these premises are in the custody of the Lawrence Warehouse Company, Lessee." It placed in charge a man named Rennie as its bonded custodian.

Rennie had previously been employed by the bankrupt as his warehouse clerk. The new employment was at the same salary as previously received from the bankrupt, and as part of the compensation to the Warehouse Company for its services the amount of Rennie's salary was included. Padlocks bearing the name of the Company, to which the custodian had the only keys were placed on the entrances to the warehouse, and the custodian kept the place locked when he was not present. With Rennie's permission the bankrupt had access to the warehouse. Except that he no longer drove a truck, Rennie continued to do the same character of work he had previously performed in and about the warehouse premises.

About July 28, 1937, the Warehouse Company issued non-negotiable warehouse reccipts by the terms of which it acknowledged receipt from the bankrupt of the steel therein described, and agreed to hold it subject to the written order of the California Bank. The receipts were delivered by the Company to the bankrupt and thereafter by the latter delivered to the California Bank as collateral for a present loan. A few days later the bankrupt negotiated for loans with appellee. As a result of the negotiations the bankrupt from time to time caused the Warehouse Company to issue additional non-negotiable warehouse receipts, which he delivered to appellee as security for loans. These, similar in form to the first, provided that the goods were to be held for the written order of appellee. The goods covered by receipts used in the transaction with the California Bank were included, in receipts subsequently issued to appellee, and the loan of the California Bank was paid off from the new loans procured from appellee.

As warehouse receipts were issued, cards showing the name of the pledgee and the amount of steel covered were placed on the various piles of steel included in the receipts.

${ }^{17}$ II3 F. 2 d $239^{\circ}$ (C. C. A. 9th 1940). 
These cards described the steel by number of pieces and their dimensions and referred to the warehouse receipts by number. While there was considerable "free" steel in the bins or shelves, it was the custom to separate the free goods from the pledged goods by a steel band or wire. No pledged steel was sold without first procuring a release. 18

The referee in bankruptcy held that there had been no actual and continued change of possession of the goods and that the purported transfer was void as against the trustee in bankruptcy. The district court reversed and was affirmed by the circuit court of appeals in the following language:

The circumstances disclose no mere colorable relinquishment of dominion over the goods. The substituted finding of the trial court of an immediate delivery to the Warehouse Company, followed by an actual and continued change of possession, is warranted by the proof. Compare Union Trust Co. v. Wilson, I98 U. S. 530, 25 S. Ct. 766 49 L. Ed. II54; Security Warehousing Co. v. Hand, 206 U. S. 4I5, 27 S. Ct. 720, 5 I L. Ed. III7, in Ann. Cas. 789.* There is nothing in McCaffey Canning Co. v. Bank of America, Iog Cal. App. 4I5, 294 P. 45, 53, to justify a contrary view.

As said in the McCaffey case, supra, "warehousing on the premises of the owner proposing to pledge his merchandise is effective when done in obedience to legal requirements." It is immaterial that the purpose of the warehousing is to enable the merchant to finance himself on the security of his goods by the use of warehouse receipts. Such is the primary and legitimate objective of modern field warehousing. Union Trust Co. v. Wilson, supra.

* [Footnote by the court] Consult authorities cited in I2 Washington L. Review 20 (1937), "The Theory of Field Warehousing."19

The Heffron case is also of interest because it involved consideration of whether the field-warehouse operation was valid under the California statute relating to mortgages of a stock of trade in bulk. ${ }^{20}$ It held that Section 3440 of the California Civil Code was repealed by the Uniform Warehouse Receipts Act in so far as it was applicable to warehoused goods, and that the subsequent enactment of Section $3440.5^{21}$ was merely a clarification of existing law, or was intended to remove doubts prompted by litigation such as the Heffron case.

In Pittman v. Union Planters National Bank \& Trust Company, ${ }^{22}$ the operation of the warehouse system was described by the court as follows:

The method of warehousing pursued by the bankrupt is known as the field warehousing system. In order to avail itself of inventory for credit purposes, the bankrupt entered into an agreement with the Nashville Warehouse and Elevator Corporation for

${ }^{18} \mathrm{Id}$. at $240-241$.

${ }^{10}$ Id. at 242.

${ }^{20}$ Cat. Civ. COde $8344^{\circ}$ (I94I).

21 "Sec. 3440.5. Same: Limitation on Application of Rule: Goods for Which Warehouse Receipt has Issued: Necessity for Retention of Copy. Section 3440 of this code shall not apply to goods in a warehouse where a warehouse receipt has been issued therefor by a warehouseman as defined in the Warehouse Receipts Act, and a copy of such receipt is kept at the principal place of business of the warehouseman and at the warehouse in which said goods are stored. Such copy shall be open to inspection upon written order of the owner or lawful holder of such receipt." (Added by Stats. 1939, p. 2840; Am. Stats. I94I, C. II42, \$I.) CAI. Civ. CODE \$3440.5 (I94I).

${ }^{22}$ I18 F. 2d 2 II (C. C. A. 6th 194I). 
the warehousing of its cottonseed. No convenient storage facilities being available, the bankrupt leased to the Warehousing Company its own storage facilities at points in Arkansas, Illinois, and Tennessee, with an agreement by the Warehousing Company that it would furnish the necessary employees for safe warehousing, and issue warehouse receipts for goods stored with it, for a consideration over and above necessary expenses, and a guarantee by the bankrupt against loss or damage in connection with such storage not due to its own fault. The Warehousing Company appointed one of the bankrupt's employees at each mill as custodian and required of him a fidelity bond, and a daily written report of quantities of cottonseed and products received, disposed of, and remaining on hand. The head warehouseman was stationed in the bankrupt's main office where he compiled and kept a master record of quantities on hand and withdrawn upon warehouse receipts made up from the daily reports furnished him by the mill warehousemen. The system followed when the R. F. C. held the collateral was continued after the banks took over the loans.

The appellant concedes that field warehousing may validly be carried on, and that the issue of warehouse receipts will afford valid security to the holders when the warehouseman takes and maintains sole, open and actual possession of the stored property. He contends that this was not true of the present system and assails the warehousing as merely colorable. While the receipts may have been in proper form, he points to numerous circumstances invalidating the security. The warehouse facilities, he says, were upon the properties of the bankrupt to which it had access; the warehousemen were its employees, devoting but a minimum of time to the warehouse business; it paid their wages and paid no rent to the Warehousing Company; until receipts were issued it exercised the right to crush and use the seed inventory, unaffected by the warehouse agreement; there was no actual change of possession of stored property since it was never handled by the Warehousing Company, nor segregated from the bulk, and was withdrawn for crushing purposes by mechanical conveyors operated by the bankrupt; the cottonseed houses were never locked and the bankrupt's operations were not interfered with by the warehouseman. ${ }^{23}$

The court held that as to the cottonseed the warehouse transaction and the warehouse receipts were valid. As will be discussed below, the warehouse operation was hẹld to be invalid as regards cottonseed products, for the reason that there was a failure to post appropriate signs or to segregate them from the other property of the bankrupt. ${ }^{24}$

\section{VI}

\section{Common Defects in Warehousing Operations}

As was stated in Pittman v. Union Planters National Bank \& Trust Company, it is essential to the validity of a warehousing arrangement that the warehouseman "have actual, open and exclusive possession" of the goods. Cases illustrative of the lack of open possession are In re Rodgers,"25 Security Warehousing Company $v$.

${ }^{28}$ Id. at 212-213.

34 McGaffey Canning Co. v. Bank of America, rog Cal. App. 415, 294 Pac. 45 (1930), contains an exhaustive review of the applicable cases on this subject at pages 426-438 (294 Pac. at 49-54). In that case the plaintiff appealed from a nonsuit. On his evidence the appellate court held that the existence of possession was a question of fact, rendered at least open to doubt by reason of such circumstances as lack of physical segregation of the warchouse from the factory by anything more than an aisle a few feet wide. Evidence on the part of the defendant to support its claim of actual possession was not before the court.

${ }^{25} 125$ Fed. 169 (C. C. A. 7th 1903). 
Hand, ${ }^{20}$ and In re Spanish-American Cork Products Company. ${ }^{27}$ In these and similar cases, either no sign or other public notice was posted by the warehouse or the signs were so inconspicuous that they were held to be ineffective.

Cases involving the lack of actual and exclusive possession usually involve both elements. Typical cases are First Camden National Bank \& Trust Company v. J. R. Watkins Company, ${ }^{28}$ Pittman v. Union Planters National Bank \& Trust Company, ${ }^{29}$ and Swetnam v. Edmund Wright Ginsberg Corporation. ${ }^{30}$ The Swetnam case does not involve field warehousing, but does involve the parallel problem of a purported possessory lien claimed by a factor. The lack of actual and exclusive possession there should be contrasted with the valid possessory lien which was sustained in In re Nathan $\&$ Cohen Company, Inc.31

The leading case of Benedict $v$. Ratner ${ }^{32}$ established the doctrine that a purported assignment of accounts receivable is invalid where in practice the assignor is not deprived of unfettered dominion over the accounts. The doctrine was applied in Lee v. State Bank \& Trust Company, ${ }^{33}$ where the assignor was not deprived of unfettered dominion over returned merchandise. The same doctrine is applicable to field-warehousing operations in which the bailor is not deprived of unfettered dominion over the warehoused goods. If the practice is to allow the borrower free access to and use of the goods, and if the lender can be charged with knowledge of the practice and acquiescence in it, the transaction is without validity, although the lender will be prottcted if it is without knowledge or notice. ${ }^{34}$

\section{VII}

\section{Conclusion}

Field warehousing is a useful method by which inventory can be made available as collateral. It accomplishes the same basic result as a trust receipt, chattel mortgage, or conditional-sale contract, but with one significant operating difference. Under the instruments just referred to, the financing agency customarily relies, as a practical matter, on the good faith and honesty of the merchant or manufacturer with regard to disposing of the inventory; if the confidence of the financing agency has been misplaced, and it is discovered that inventory has been sold without accounting for the proceeds, the financing agency has little or no protection against the honest purchaser, and a limited claim to proceeds. ${ }^{35}$ However, in the field-warehousing operation the warehouse is in charge of a custodian who is normally covered with a fidelity bond. Although he usually is a former employee of the borrower,

${ }^{30} 206$ U. S. 4 I5 (1907), also involving lack of possession.

272 F. 2 d 203 (C. C. A. $4^{\text {th }}$ 1924).

28 r22 F. $2 d 826$ (C. C. A. 3rd r 94 I).

${ }^{20}$ II8 F. 2d 2 II (C. C. A. 6th I94I).

${ }^{20}$ r28 F. $2 d$ I (C. C. A. $2 d$ 1942).

${ }^{32} 58$ F. $2 d 670$ (S. D. N. Y. I932), rev'd on another point, Irving Trust Co. v. Commercial Factors Corp., 68 F. 2d 864 (C. C. A. 2d 1934).

${ }^{32} 268$ U. S. 353 (I925).

${ }^{22} 54$ F. 2 d 518 (C. C. A. $2 d$ 1931).

"In re C. A. Taylor Log \& Lumber Co., $4 \mathrm{r}$ F. 2d 249 (W. D. Wash. x925).

${ }^{28}$ See Uniform Trust Receipts Act, \$59, 10; I68 A.L.R. 368, supplementing 49 A.L.R. 300, 87 A.L.R 314, and ror A.L.R. 460; 88 A.L.R. rog, supplementing 47 A.L.R. 85 . 
the personal responsibility thus focused on an individual seems to be justified by experience; and in case of doubt such an employee could be replaced by the lender's own representative.

There is never-ending conflict between the proponents of unsecured credit and the advocates of secured credit. Apart from litigation, this conflict is well known to those who have participated in the drafting of statutes relating to the assignment of accounts receivable, trust receipts, factor's liens, and similar matters. On principle, the writer believes that the greater social interest lies in facilitating the granting of secured credits and in establishing practical procedures whereby this may be done without legal risk. So long as legal risk is involved, the terms upon which such credit can be obtained are bound to be expensive, and expensive credit is economically wasteful. The establishment of simple and safe procedures removes a large part of the gamble and enables such credit to be extended by banks and others who are not gamblers but legitimate merchants of credit. The law should treat field warehousing as a valid and safe procedure. 